УДК 351.74(075.8)

DOI https://doi.org/10.32849/2663-5313/2020.7.26

Олена Коломієць,

канд. психол. наук,

стариий викладач кафедри тактичної підготовки

Національної академії внутрішніх справ

Юрій Демченко,

стариий викладач кафедри тактичної підготовки

Начіональної академії внутрішніх справ

\title{
ЗАБЕЗПЕЧЕННЯ БЕЗПЕКИ ПОЛІЦЕЙСЬКИХ ПІД ЧАС ЗУПИНЕННЯ ТРАНСПОРТНОГО ЗАСОБУ
}

У статті на основі аналізу норм чинного законодавства Украӥни та узагальнення практично20 досвіду несення служби в органах Начіональної поліиї̈ розглянуто питання забезпечення безпеки поліщейських під час зупинення транспортного засобу з невідомими ризиками. Звернено увагу на той факт, що при настанні надзвичайної ситуації на транспорті, як правило, виникає загроза життю та здоров'ю людей, спричиняється велика матеріальна шкода, а іноді й загострюється соціальна напруга. Для попередження та припинення означених негативних наслідків залучаються сили й ресурси органів виконавчої влади, особливе місие серед яких займає Начіональна полічія України. Встановлено, що рівень забезпечення особистої безпеки поліщейських прямо залежить від рівня їхньої професійної підготовки, а успішна реалізація покладених на полічію завдань у сфері безпеки дорожнього руху - від обраної поліщейськими тактики та злагодженості їхніх дій. Проаналізовано положення Закону України «Про Національну поліцію» щодо підстав зупинення транспортного засобу, алгоритму дій полічейського при спілкуванні з водієм. Визначено обставини, за яких працівникам поліиї дозволяється здійснювати переслідування автомобіля та правила переслідування. Звернено увагу на тактику зупинки при переслідуванні, варіанти наближення до транспортного засобу, особливості огляду транспортного засобу для перевірки, а також порядок дій полічейських у випадку наявності інформації про перебування осіб або транспортного засобу у розшуку. Акцентовано увагу на порядку дій працівників полічії у виняткових обставинах, за яких патрульний полічейський може попросити водія, а за потреби і пасажирів, вийти з транспортного засобу. Охарактеризовано особливості здійснення прикриття та взаємодії під час зупинення транспортного засобу з високим ступенем ризику. Наголошено, що ефективність діяльності прачівників поліції у сфері безпеки дорожнього руху передбачає наявність певного рівня захищеності самих правоохоронців, оскільки, виконуючи свої службові обов'язки, вони нерідко опиняються у небезпечних умовах або стають об'єктом злочинних посягань.

Ключові слова: безпека, ризик, транспортний засіб, водій, поліцейський, тактика, затримання.

Постановка проблеми. Аналіз наукових джерел, загальнодержавних та галузевих нормативних актів яскраво демонструє стурбованість надто високим рівнем смертності і травматизму від дорожньо-транспортних пригод. Дійсно, за даними Всесвітньої організації охорони здоров'я це є однією з найбільших проблем охорони здоров'я, а за прогнозами у 2030 році дорожньо-транспортні пригоди можуть стати однією 3 основних п’яти причин смертності людей у світі. На жаль, українська статистика автопригод також демонструє суттєве прогрішення ситуації. У зв'язку з цим питанню безпеки на дорогах відводиться особлива роль. Водночас необхідно зазначити, що ані більш суворі покарання для учасників дорожнього руху, ані просвітницька робота в цій сфері суттєво на ситуацію не вплинули. Очевидно, про- блема носить комплексний характер і стосується як учасників дорожнього руху, так і виконавчих органів, на які покладається обов'язок забезпечувати публічну безпеку й порядок.

Національна поліція України є функціональною підсистемою охорони публічного порядку у складі єдиної державної системи запобігання i реагування на надзвичайні ситуації, покликаною залучати свої сили і засоби для забезпечення конституційного права громадян на захист життя і здоров'я. Разом з тим практична діяльність органів Національної поліції, ефективність заходів щодо протидії аваріям та катастрофам на транспорті, не завжди відповідають вимогам забезпечення необхідного рівня безпеки як для громадян, так і для правоохоронців. У більшості випадків причини проблем поро- 
джені з одного боку, недосконалістю чинного законодавства, недостатнім рівнем ефективності управлінської та контрольно-наглядової діяльності уповноважених органів і їхніх посадових осіб, а з другого - відсутністю достатнього досвіду та рівня тактичної підготовки поліцейських. Згідно із Законом України «Про національну поліцію», який визначає правові засади організації та діяльності Національної поліції України, до повноважень поліції належить регулювання дорожнього руху та здійснення контролю за дотриманням Правил дорожнього руху його учасниками, супроводження транспортних засобів у випадках, визначених законом [1]. Отже, для усунення або запобігання дорожньо-транспортним пригодам необхідна підготовка відповідних заходів, змістом яких $\epsilon$ реалізація норм чинного законодавства та фахова підготовленість працівників поліції до найбільш доцільних, активних і рішучих дій в складних чи небезпечних умовах виконання службових обов'язків.

Варто відзначити, що питання діяльності Національної поліції України у сфері безпеки дорожнього руху не оминалися увагою науковців, зокрема це питання досліджували: С.М. Гусаров, О.В. Кузьменко, С.Г. Братель, Ю.А. Тихомиров, В.О. Заросило, Д.І. Сирота, В.Ю. Кікінчук, А.М. Луцик, Є.В. Скрипа та багато інших. Однак, незважаючи на чималу кількість наукових розробок, у більшості робіт проблема безпеки працівників поліції при здійсненні контролю за дотриманням Правил дорожнього руху містить ще чимало дискусійних аспектів.

Мета статті - надати характеристику заходів особистої безпеки і тактичних дій працівників поліції при зупинці та переслідуванні транспортного засобу з невідомим ступенем ризику.

Виклад основного матеріалу. Враховуючи особливості діяльності Національної поліції у сфері забезпечення безпеки дорожнього руху, перш за все необхідно приділити увагу підставам зупинення транспортного засобу. Так, згідно із Законом України «Про Національну поліцію» цими підставами є: порушення водієм Правил дорожнього руху, очевидні ознаки, що свідчать про технічну несправність транспортного засобу, інформація, що свідчить про причетність водія або пасажирів транспортного засобу до вчинення дорожньо-транспортної пригоди, кримінального чи адміністративного правопорушення, а також якщо транспортний засіб перебуває в розшуку, або необхідно здійснити опитування водія чи пасажирів про обставини вчинення дорожньо-транспортної пригоди, кримінального чи адміністративного правопорушення, свідками якого вони могли бути тощо. Крім того, поліцейські мають право зупиняти транспортний засіб у разі необхідності залучити водія до надання допомоги іншим учасникам дорожнього руху або поліцейським, або як свідка під час оформлення протоколів про адміністративні правопорушення чи матеріалів дорожньо-транспортних пригод. Поліцейський зобов'язаний поінформувати водія про конкретну причину зупинення ним транспортного засобу 3 детальним описом підстави зупинки. Під час звернення до водія поліцейський зобов’язаний назвати своє прізвище, посаду, спеціальне звання та пред'явити на вимогу службове посвідчення, надавши можливість ознайомитися 3 викладеною в ньому інформацією, не випускаючи його з рук [1].

Водій має право здійснювати аудіота відеофіксацію як спілкування зі співробітником поліції, так і всіх його дій при виконанні ним своїх публічних службових обов'язків. При цьому водій повинен пам'ятати, що його право закінчується там, де починається право іншої людини. Така фіксація не повинна заважати виконанню службових обов'язків поліцейським. Зупинка транспортного засобу правопорушника для припинення порушень правил дорожнього руху під час руху патрульним автомобілем повинна здійснюватись 3 використанням спеціальних звукових та світлових пристроїв з дотриманням заходів безпеки.

Працівникам поліції забороняється, крім крайньої необхідності, зупинення транспортного засобу на підйомах, мостах, естакадах, шляхопроводах, крутих поворотах, інших ділянках доріг з обмеженою оглядовістю [2]. Під час зупинки транспортного засобу обов'язково слід враховувати характер та місце зупинки, тип транспортного засобу, кількість осіб у салоні автомобіля. Підготовка до зупинення транспортного засобу передбачає не лише визначення поліцейським місця зупинки, а й повідомлення оперативному черговому про наміри, своє місцезнаходження, номерний знак автомобіля та іншу додаткову інформацію.

Що до безпосереднього зупинення транспортного засобу, то воно може здійснюється за допомогою гучномовця або з використанням світлових сигналів (маячків), а у виняткових випадках - навіть жестами. Отже, поліцейські вмикають проблискові маячки (червоний вимикається після зупинки обох транспортних засобів), та зупинивши службовий транспортний засіб за 3-5 метрів до підозрюваного транспортного засобу, займають найбільш безпечну позицію [3, с. 72]. 
Зауважимо, що поліцейські пішого патруля не можуть здійснювати зупинення транспортних засобів, крім випадків крайньої необхідності. При виявленні вчинення правопорушення такий поліцейський передає відповідну інформацію, у тому числі щодо транспортного засобу, черговому та автопатрулям у відповідних квадратах.

Порядок наближення поліцейських до транспортного засобу у темний період доби передбачає відповідну послідовність дій, а саме: слід здійснити перевірку безпеки попутного потоку транспортних засобів, відрегулювати світло фар на службовому автомобілі, перевірити спорядження, увімкнути body камеру, вийти із службового транспортного засобу.

Таким чином, з метою забезпечення особистої безпеки, до зупинки транспортного засобу, під час фактичної зупинки та після здійснення зупинки поліцейському потрібно постійно оцінювати ситуацію. Наближатись до транспортного засобу можна ззаду, з боку водія або зі сторони пасажира - за потреби. Упевнитись у відсутності небезпеки поліцейський може, оглянувши салон крізь вікна Вимагати у водія зупинити роботу двигуна, а за потреби - включити світло в салоні, слід стоячи на безпечній відстані від транспортного засобу, при цьому поліцейський повинен продовжувати спостерігати за діями водія і пасажирів. Документи від водія приймаються вільною рукою для збереження можливості користуватись вогнепальною зброєю у разі необхідності. Альтернативними варіантами може бути наближення зі сторони пасажира, або наближення двох поліцейських з різних боків [4, с. 41].

Що ж стосується алгоритму забезпечення особистої безпеки поліцейських при зупинці транспортного засоби, то він прописаний у окремих положеннях Закону України «Про Національну поліцію». Так, поліцейський 3 дотриманням вимог забезпечення власної безпеки, наближається до водія зупиненого транспортного засобу, привітавшись 3 водієм, поліцейський має представитись (1, ст. 18, ч. 3 ЗУ НП) та проінформувати про проведення відео фіксації (ст. 40 ЗУ НП), а також повідомити причину зупинки (ст. 35 ЗУ НП), потім перевірити посвідчення водія, свідоцтво про державну реєстрацію транспортного засобу, інші документи відповідно до законодавства (п. 2.1, 2.4 ПДР). У разі необхідності - перевірити транспортний засіб та особу водія по базі «АРМОР», а також здійснити інші дії, зокрема, скласти адміністративні документи. При цьому, водій та пасажири повинні залишатись у транспортному засобі.
Окремої уваги заслуговують виняткові обставини, за яких патрульний поліцейський може попросити водія, а за потреби і пасажирів, вийти із транспортного засобу це підозра щодо вчинення водієм або пасажирами автомобіля адміністративного правопорушення, злочину. Усунення адміністративного правопорушення чи здійснення перевірки VIN-коду автомобіля - теж може бути підставою для вимоги водію вийти з транспортного засобу. Як уже зазначалося, водій та пасажири можуть бути залучені в якості свідків або на допомогу при надзвичайній події.

При спілкуванні з водієм, який вийшов iз транспортного засобу, необхідно покинути проїжджу частину. Розміщуватися при цьому слід за принципом «контакт - прикриття».

«Контакт - прикриття» $є$ стандартною процедурою забезпечення безпеки на місці події, яка застосовується за участі двох чи декількох поліцейських та одного чи декількох суб'єктів (підозрюваних осіб). Поліцейський, який здійснює контакт, розмовляє 3 підозрюваним, забезпечує документальне оформлення, проводить поверхневий огляд, здійснюе радіозв'язок тощо. Головним завданням поліцейського, який здійснює прикриття - $€$ захист поліцейського, який здійснює контакт. Саме поліцейський-прикриття повинен вибрати оптимальну позицію для спостереження та контролювати дії підозрюваних.

Таким чином, під час огляду транспортного засобу і спілкування із водієм, поліцейським рекомендується обирати безпечну відстань, не випускати водія і пасажирів з поля зору, а також не повертатися до них спиною. Поліцейський має використовувати максимально освітлену частину (ділянку) дороги (вулиці) або фари патрульного автомобіля, за потреби.

Принагідно зауважимо, що поліцейським забороняється сідати до зупиненого транспортного засобу або садити осіб до службового авто (якщо інше не передбачено відомчими інструкціями, за погодженням з безпосереднім керівником). Також працівникові поліції забороняється підходити до зупиненого транспортного засобу зі з боку фар чи стояти між особою та поліцейським, чию безпеку він забезпечує.

У разі виявлення інформації про перебування осіб або транспортного засобу у розшуку, поліцейські займають позиції, які дозволять їм страхувати один одного, забезпечувати особисту безпеку та безпеку третіх осіб. Про таку інформацію негайно повідомляють оперативного чергового 
та безпосереднього керівника. У подальшому вживаються заходи для затримання такого транспортного засобу, у т.ч. шляхом його блокування.

Згідно зі статтею 122-2 КУпАП підставою для переслідування $є$ невиконання водієм вимоги патрульного про зупинку транспортного засобу, яка є обов'язковою для всіх учасників дорожнього руху (у разі невиконання таких вимог патрульний здійснює переслідування та зупинку транспортного засобу). Також підставою для переслідування може бути отримана патрульним інформація про транспортний засіб або осіб, які перебувають в даному транспортному засобі. Положення статей 173, 185, 130 КУ ПАП визначають, що якщо поведінка водія та/або пасажирів не відповідає обстановці - це теж може бути причиною переслідування транспортного засобу [5].

Правила здійснення переслідування полягають у наступному: 1) під час переслідування транспортного засобу екіпаж патрульної поліції вмикає відповідні світлові та сигнальні пристрої; 2) екіпаж повідомляе через радіостанцію (інші засоби зв'язку) марку, модель, колір, транспортного засобу, який вони переслідують; 3) через гучномовець екіпаж патрульної поліції закликає водія транспортного засобу зупинитися.

Тактика зупинки при переслідуванні визначає, що безпосередній контакт з транспортним засобом, який переслідують, може бути здійснений виключно в разі крайньої необхідності. Вогнепальна зброя застосовується тільки за обставин, передбачених статтею 46 Закону України «Про Національну поліцію» і лише у випадках, якщо патрульний впевнений в ефективності та безпеці їі застосування. Найбільш ефективним способом зупинки переслідуваного транспортного засобу є його блокування іншими транспортними засобами.

Окремо слід вказати, що виконання працівниками поліції службових завдань у сфері забезпечення безпеки дорожнього руху нерідко передбачає контакт 3 підозрілими особами. В такому разі поліцейський має право наказати водію зупинити двигун, тримати руки так, щоб їх бачити, вийти 3 транспортного засобу і підійти до патрульного автомобіля. Таким чином, один поліцейський-контакту контролює поведінку водія, подаючи чіткі, прості команди, в той час як інші - контролюють пасажирів транспортного засобу [6, с. 10].

Огляд транспортного засобу для перевірки теж має свої особливості. Насамперед, необхідно дотримуватися напрямку огляду транспортного засобу (наприклад: за годин- никовою стрілкою чи проти, квадратами), використовувати ліхтарик, перевіряти усі можливі місця, не пошкоджуючи при цьому конструкцію автомобіля.

У раз скоєння тяжкого злочину або якщо зростає ризик для поліцейських та інших громадян, послідовність зупинки транспортного засобу подібна до зупинки з невідомим ступенем ризику і передбачає кілька необхідних заходів безпеки, а саме: наявність прикриття та підтвердження інформації оперативному черговому.

У разі зупинення транспортного засобу 3 високим ступенем ризику, підстави для переслідування такі ж, як для інших учасників дорожнього руху. У разі невиконання вимог патрульного він має право здійснювати переслідування та зупинення транспортного засобу, зокрема: 1) під час переслідування транспортного засобу поліцейський обов'язково вмикає відповідні світлові та сигнальні засоби на патрульному автомобілі; 2) про здійснення переслідування обов'язково повідомляє оперативного чергового та безпосереднього керівника, із зазначенням марки, моделі, кольору, державного номерного знака переслідуваного транспортного засобу; 3) через гучномовець закликає водія переслідуваного транспортного засобу зупинитися; 4) про напрям і характер руху переслідуваного транспортного засобу систематично повідомляє чергового.

Окремо слід охарактеризувати особливості здійснення прикриття та взаємодії під час зупинення транспортного засобу з високим ступенем ризику. Так, основний підрозділ обирає місце для зупинки і розташовується за 10-15 метрів позаду зупиненого транспортного засобу, керує підрозділами прикриття, додатковими підрозділами та організовуе затримання осіб, які перебувають в зупиненому транспортному засобі. Лівий підрозділ зупиняється ліворуч від основного підрозділу під кутом і прикриває його автомобіль. У свою чергу, правий підрозділ прикриття зупиняється праворуч від основного підрозділу в один ряд з основним автомобілем. Правий підрозділ-прикриття $є$ відповідальним за радіозв'язок під час зупинки та здійснюе перевірку транспортного засобу після виходу всіх підозрюваних з автомобіля.

При затриманні підозрюваних осіб, водію зупиненого транспортного засобу подають команду розвернутися обличчям до патрульних автомобілів. Водія розміщують за патрульними автомобілями в позицію для затримання, застосовують кайданки, проводять опитування та поверхневу перевірку. Таку ж послідовність поліцейські повторюють в процесі затримання всіх осіб, які пере- 
бували у транспортному засобі, виводячи їх по черзі [7, с. 64].

Із зазначеного вище випливає, що найбільш оптимальна і безпечна послідовність переміщення та затримання підозрюваних осіб передбачає наступні дії: максимальне використання освітлення для отримання переваги, виведення водія з авто, утримання всіх пасажирів в автомобілі і робота з кожним окремо, контроль поведінки і застосування кайданків перш ніж завести підозрюваного за автомобіль основного підрозділу, проведення поверхневого огляду поліцейським, який саджає особу в автомобіль.

\section{Висновки}

Завершуючи дослідження, слід констатувати, що в умовах сьогодення безпека на транспорті - це складне соціальне явище, яке не обмежується дисциплінованістю водіїв і пішоходів, станом доріг, зростанням автомобільного парку чи якістю організації дорожнього руху. Над вирішенням проблем запобігання дорожньо-транспортних пригод та розробкою заходів для іх усунення постійно працює особовий склад Національної поліції, виконуючи тим самим одне з основних своїх завдань.

Діяльність працівників поліції при забезпеченні безпеки дорожнього руху здебільшого пов'язана з різноманітними загрозами i стресовими ситуаціями. Своєрідність впливу небезпеки полягає в іiї постійній потенційній присутності. На жаль, в Україні поки що не досягнуто позитивних зрушень в удосконаленні законодавства та подоланні негативних суспільних тенденцій, а діюча система управління, нагляду за дотриманням безпеки дорожнього руху функціонує в умовах організаційної неузгодженості та базується на засадах мінімально достатніх нормативно-правових вимог.

\section{Список використаних джерел:}

1. Про Національну поліцію : Закон України від 2 липня 2015 р. № 580-VIII. Верховна Рада України. URL: https://zakon.rada.gov.ua/ laws/show/580-19 (дата звернення: 03.06.2020).

2. Про Правила дорожнього руху : Постанова Кабінету Міністрів України від 10 жовтня 2001 р. № 1306 / Верховна Рада Украӥни. URL: https:// zakon.rada.gov.ua/laws/show/1306-2001-\%D0\%BF

3. Тактико-спеціальна підготовка працівників Національної поліції : навчальний посібник. / О. І. Тьорло та ін. Львів : ЛьвДУВС, 2018. 480 с.

4. Тактико-спеціальна підготовка : навчальний посібник / Є.В. Гузенко та ін. Київ : НАВС, 2014. 155c.

5. Кодекс України про адміністративні правопорушення : Закон України від 12 грудня 1984 р. № 8073-X / Верховна Рада України. URL: https://zakon.rada.gov.ua/laws/show/80731-10. (дата звернення: 09.05.2020).

6. Реагування органів та підрозділів Національної поліції на повідомлення про правопорушення або інші події : методичні рекомендації / В.Л. Костюк та ін. - Київ : НАВС, 2017. 44 с.

7. Чмелюк В.В., Грищук В.Л., Бадьора С.М. Основи тактичної підготовки працівників правоохоронних органів : навчальний посібник. Ірпінь : Університет ДФС України, 2019. 218 с.

Olena Kolomiets, Yurii Demchenko. Ensuring the safety of police officers when stopping a car

The article is devoted to the analysis of the current legislation of Ukraine and the generalization of practical experience of service in the National Police to ensure the safety of police officers when stopping a vehicle with unknown risks. Attention is drawn to the fact that in the event of a transport emergency, as a rule, there is a threat to human life and health, great material damage is caused, and sometimes social tensions are exacerbated. To prevent and stop these negative consequences, the forces and resources of the executive authorities are involved, a special place among which is occupied by the National Police of Ukraine. It is established that the level of personal security of police officers directly depends on the level of their professional training, and the successful implementation of the tasks assigned to the police in the field of road safety - on the tactics chosen by police and the coherence of their actions. The provisions of the Law of Ukraine "On the National Police" on the grounds for stopping a vehicle, the algorithm of actions of a police officer when communicating with a driver are analyzed. The circumstances under which police officers are allowed to pursue a car have been identified. Attention was paid to the rules of stopping during the pursuit, options for approaching the vehicle, the features of the inspection of the vehicle for inspection, as well as the sequence of actions of police officers in case of information about the search of the vehicle. Emphasis is placed on safety rules for police officers in exceptional circumstances, under which a patrol officer may ask the driver to get out of the vehicle. It is emphasized that the effectiveness of police activities in the field of road safety requires a certain level of protection, because in the performance of their duties, police officers often find themselves in dangerous conditions or become the object of criminal encroachment. To prevent traffic accidents, it is necessary to prepare appropriate measures, the content of which is the implementation of current legislation and professional training of police officers for the most appropriate, active and decisive action in difficult or dangerous conditions.

Key words: safety, risk, vehicle, driver, policeman, tactics, detention. 